TIO FATURHOMAN DAN TARUNASENA

ROLE PLAYING GAME TANPA GADGET (PENELITIAN TINDAKAN KELAS DALAM PEMBELAJARAN

SEJARAH DI KELAS XI IPS C MAN I KOTA BANDUNG)

\title{
ROLE PLAYING GAME TANPA GADGET (Penelitian Tindakan Kelas dalam Pembelajaran Sejarah di Kelas XI IPS C MAN I Kota Bandung)
}

\author{
Oleh: \\ Tio Faturhoman dan Tarunasena ${ }^{1}$
}

\begin{abstract}
Ideally, the students'goal in carrying out the activities oflearning is to obtain behavioural change. But it was contradictory wherein the reality found during observations in Grade XI IPS C. During learning History takes place, students were doing activities that improper with the learning agenda. The cause as the use of learning methods that irrelevant to each student's character. Based on the results' observations, the author realized the proper method for students of Grade XI IPS C is Role Playing. Therefore the author conducted a classroom action research with the research formulation "How to apply the Role Playing method in learning History to improve directed learning activities for students of Grade XI IPS C in MAN I Bandung?” This Classroom Action Research (CAR) based on Kemmis \& Taggart design. In this design, CAR is carried out in several cycles which are divided into 4 (four) stages namely: Planning, Action, Observation and Reflection. After applying the Role Playing method, the author found an increasing towards student learning activities both physically and mentally. Thus it can be concluded that the Role Playing method is strongly effective in directing student activities in learning History.
\end{abstract}

Keywords: Classroom Action Research, Learning Activities, Learning Methods, Role Playing

\section{PENDAHULUAN}

Menurut Susanto (2013, hlm. 5) kegiatan pembelajaran proses perubahan siswa baik dalam segi kognitif, afektif maupun psikomor. Supaya memperoleh perubahan tersebut, siswa harus melakukan segala aktivitas yang berkaitan dengan agenda pembelajaran, dengan kata lain aktivitas belajar. Pandangan Ilmu Jiwa lama menafsirkan Aktivitas Belajar sepenuh dilakukan oleh guru, sedangkan Pandangan Ilmu Jiwa Lama menyatakan siswalah yang semestinya dominan di kelas selama pembelajaran berlangsung (Afif, 2012).

Setelah hampir 2 dekade sejak dimulainya abad 21, definisi aktivitas belajar lebih mengikuti pandangan ilmu jiwa baru. Maka dari itu, secara ideal siswa harus lebih aktif dalam mengikuti kegiatan pembelajaran. Sayangnya kondisi ideal ini tak sesuai dengan realita yang ditemukan dalam observasi partisipasi di kelas XI IPS C di MAN I Kota Bandung pada tanggal 21 dan 23 Februari 2018.

${ }^{1}$ Tio Faturhoman adalah mahasiswa Departemen Pendidikan Sejarah FPIPS UPI, Tarunasena adalah Dosen Pembimbing. Penulis dapat dihubungi di alamat email: Sentinelof48@gmail.com. 
Dalam observasi partisipasi ini, Penulis melakukan pengajaran pembelajaran Sejarah pada 32 siswa kelas XI IPS C dengan metode konvensional seperti ceramah dan penugasan. Pada hari pertama observasi, penulis melakukan ceramah pada siswa. Pada awalnya siswa terlihat sangat fokus memperhatikan penuturan materi oleh penulis. Namun memasuki jam kedua dalam kegiatan ini, hampir siswa kehilangan fokus. sebagian besar dari mereka melakukan aktivitas yang tak ada hubungannya dengan pembelajaran sejarah ini seperti tidur, bermain gadget, mengobrol dengan teman sebangku dan bahkan ada yang secara bergiliran pergi ke toilet.

Menurut Maharani dkk (2018, hlm. 44) Penggunaan metode yang mengembangkan kecerdasan interpersonal dapat mengurangi tingkat kejenuhan siswa selama mengikuti kegiatan pembelajaran Sejarah. Maka dari itu, pada pertemuan selanjutnya penulis menerapkan metode penugasan untuk mengajar materi Sejarah. Pada sesi pembukaan, penulis membagi siswa menjadi kelompokkelompok kecil yang masing-masing diberi tugas menganalisis karikatur yang menggambarkan kebangkitan nasionalisme di Cina dan India.

Penulis memberikan waktu selama 45 menit untuk mengerjakan tugas ini. Bukannya bekerja samak menganalisis karakatur tersebut, penulis melihat sebagian besar kelompok mengandalkan satu anggotanya untuk mengerjakan tugas analisis karakatur ini sendirian sedangkan sisa anggota lainnya melakukan aktivitas yang tak sesuai dengan agenda kelas. Setelah waktu pengerjaan tugas habis, penulis mempersilahkan setiap kelompok untuk melakukan presentasi secara bergiliran. Selagi perwakilan kelompok berbicara di depan kelas, mayoritas siswa tidak memperhatikannya.

Berdasarkan observasi yang telah dilakukan, penulis menyimpulkan permasalahan yang ada pada kelas XI IPS C ini adalah aktivitas belajar yang terarah selama mempelajarai Sejarah. Faktor dari permasalahan ini adalah pemilihan metode yang tak disesuaikan dengan karakteristik siswa. Untuk menemukan metode yang tepat bagi siswa kelas XI IPS C, penulis berkaca pada pernyataan Komisi Pendidikan Abad 21 (dalam Trianto, 2010, hlm. 5) yang merekomendasikan strategi untuk menyukseskan proses pendidikan dengan mendorong siswa untuk belajar mengenal lingkungan di sekitarnya, berinteraksi dengan sesamanya, dan mempraktekan apa yang dipelajarinya. Pernyataan Komisi tersebut didukung oleh Djamarah (2002, hlm. 67) yang menjelaskan bahwa belajar sambil melakukan lebih mendatangkan hasil bagi peserta didik, karena kesan yang tersimpan dalam benak mereka akan lebih bertahan lama.

Berdasar rekomendasi Komisi Pendidikan Abad 21 dan pernyataan Djamarah, penulis menyimpulkan bahwa metode yang digunakan haruslah memberikan kebebasan bagi para siswa untuk menyalurkan aktivitas belajar siswa, namun tetap diawasi oleh guru supaya lebih terarah. Maka dari itu penulis memilih metode Role Playing sebagai metode yang tepat bagi siswa kelas XI IPS C MAN I Kota Bandung.

Untuk mengatasi permasalahan aktivitas belajar uang tidak terarah ini, penulis melakukan penelitian tindakan 
TIO FATURHOMAN DAN TARUNASENA

ROLE PLAYING GAME TANPA GADGET (PENELITIAN TINDAKAN KELAS DALAM PEMBELAJARAN

SEJARAH DI KELAS XI IPS C MAN I KOTA BANDUNG)

kelas di kelas XIIPSCMANI Kota Bandung. Rumusan masalah dalam penelitian ini adalah "Bagaimana penerapan metode Role Playing dalam pembelajaran Sejarah untuk meningkatkan aktivitas belajar yang terarah pada Siswa kelas XI IPS C di MAN I Bandung?” Tujuan dari penelitian ini adalah "menerapkan metode Role Playing dalam pembelajaran Sejarah untuk meningkatkan aktivitas belajar yang terarah pada Siswa kelas XI IPS C di MAN I Bandung."

Manfaat dari penelitian ini berupa manfaat praktis yang dapat dirasakan oleh berbagai pihak. Misalnya, hasil penelitian inibisa dijadikan sebagai referensibagipara guru untuk menyelesaikan permasalahan yang dihadapi dalam kelasnya. Selain itu, hasil penelitian ini bisa menjadi sumbangan pemikiran untuk usahausaha peningkatan kualitas pembelajaran Sejarah di MAN I Kota Bandung. Terakhir, penelitian ini dapat dijadikan referensi bagi penelitian tindakan kelas selanjutnya yang berfokus pada permasalahan yang sama.

\section{METODE PENELITIAN}

Metode penelitian yang digunakan adalah Penelitian Tindakan Kelas. Hopkins (dalam Mardiani, 2015, hlm. 24) menjelaskan penelitian tindakan kelas sebagaipenelitianyangmengkombinasikan prosedur penelitian dengan tindakan substantif, suatu tindakan yang dilakukan dalam disiplin inquiri, atau suatu usaha seseorang untuk memahami apa yang terjadi, sambil terlibat dalam sebuah prosedur perbaikan dan perubahan. Pernyataan Hopkins ini menyiratkan karakteristik penelitian tindakan kelas yang dilakukan dalam berbagai tahapan, sesuai dengan aturan yang ditetapkan dan bertujuan untuk memperbaiki sekaligus merubah cara belajar siswa.

Desain penelitian tindakan kelas yang penulis gunakan diadopsi dari Kemmis \& Taggart yang membentuk pola spiral dari setiap siklus. Dalam penelitian ini, peneliti harus menempuh beberapa siklus yang terdiri dari 4 tahapan: Perencanaan, Tindakan, Observasi dan Refleksi. Setelah satu siklus dilaksanakan, akan dilanjutkan ke siklus yang tahapannya telah dikembangkan berdasarkan refleksi siklus sebelumnya. Penelitian akan dinyatakan selesai setelah penulis menemukan titik jenuh. (Sugiarto, 1997).

Lokasi yang ditetapkan sebagai tempat penelitian adalah Madrasah Aliyah Negeri 1 Bandung yang beralamat di Jalan Haji Alpi No.40, Kelurahan Cibuntu, Kecamatan Bandung Kulon, Kota Bandung, Provinsi Jawa Barat. Penelitian ini dilakukan pada semester genap tahun ajaran 2017/2018. Subjek penelitian yang penulis pilih adalah siswa- siswa kelas XI IPS C yang terdiri dari 17 siswa laki-laki dan 15 siswa perempuan, jika dijumlahkan maka total siswa dalam kelas ini adalah 32 orang.

Metode pembelajaran yang digunakan oleh penulis adalah Role Playing. Metode ini merupakan turunan dari model pembelajaran Simulasi. Role Playing adalah aktivitas yang dirancang sedemikian rupa sehingga siswa dapat memperoleh perubahan perilaku (penambahan pengetahuan dan keahlian) dengan memainkan sebuah peran dalam sebuah permaianan (Zaini dkk, 2008).

Terdapat 2 teknik pengumpulan data yang digunakan oleh penulis. Teknik pertama adalah Observasi. Jenis observasi yang dilakukan adalah Observasi 
Partisipasi, Penulis terlibat dalam kegiatan pembelajaran sebagai pengajar sekaligus mengamati aktivitas siswa selama kegiatan tersebut berlangsung. Observasi ini dilakukan untuk mengetahui peningkatan aktivitas fisik siswa selama kegiatan belajar dengan metode Role Playing berlangsung. Teknik selanjutnya adalah Tes Tertulis. Setelah Role Playing dilakukan, masingmasing siswa akan diberikan tes uraian yang menguji aktivitas mental mereka.

Terdapat 2 jenis data yang diperoleh dalam penelitian ini. Data pertama adalah Data kualitatif yang didapat dari observasi. Arifin (2011, hlm. 142), mengemukakan bahwa data kualitatif merupakan data yang dihasilkan dari pengamatan terhadap proses suatu tindakan. Data ini disajikan melalui narasi, deskripsi dan cerita. Data selanjutnya adalah data kuantitatif yang didapatkan dari observasi dan tes uraian. Menurut Aedi (2010, hlm. 06), "Data kuantitatif adalah data yang berbentuk angka atau bilangan." Data tersebut disajikan dalam bentuk Tabel dan Diagram.

Validasi data dilakukan dengan 3 cara. Cara yang pertama adalah dengan member check, memeriksa kembali data yang telah diperoleh dari hasil observasi untuk memastikan validitas data tersebut (Wiriaatmadja, 2007). Selain itu, validasi dilakukan melalui Audit Trail untuk menemukan adanya kesalahan-kesalahan dalam pelaksanaan penelitian. Teknik terakhir dalam validasi data adalah Expert Opinion. Dalam penelitian ini, penulis dibimbing oleh 2 dosen pembimbing. Penulis dapat memanfaatkan nasihat dan saran dari kedua pembimbing itu dalam validasi data ini.

Menurut Issac (dalam Muslich 2010, hlm. 144) penelitian tindakan kelas ini didesain untuk memecahkan masalah- masalah yang diaplikasikan secara langsung di dalam ajang kelas atau dunia kerja. Berdasarkan pernyataan Issac, penelitian tindakan yang dilakukan oleh penulis ini bertujuan untuk meningkatkan aktivitas belajar siswa kelas XI IPS C MAN I Kota Bandung. Indikator dari tercapainya tujuan ini adalah adanya peningkatan aktivitas fisik dan mental siswa dari setiap siklus pertama hingga siklus terakhir.

\section{HASIL PENELITIAN}

\section{Pelaksanaan Siklus I}

Langkah pertama dalam penelitian tindakan kelas ini adalah perencanaan. Hal-hal yang dilakukan adalah :

a. Menyusun Rencana Pelaksanaan Pembelajaran (RPP) yang berdasarkan silabus mata pelajaran Sejarah untuk kelas XI IPS. Materi yang tercantum dalam RPP ini adalah Politik Etis. RPP ini menjadi acuan dalam pelaksanaan kegiatan pembelajaran nanti. Dalam penyusunan RPP ini, Penulis dibimbing oleh dosen pembimbing.

b. Menyusun Skenario Role Playing yang disesuaikan dengan materi pembelajaran. Dikarenakan materi yang akan dibahas adalah Politik Etis, maka skenario yang dimainkan adalah sidang parlemen Belanda yang memperdebatkan Undang-undang politik etis.

c. Menyiapkan properti yang mendukung pelaksanaan kegiatan Role Playing. Properti yang dibuat adalah rancangan undang-undang yang membahas upaya balas budi Belanda terhadap Pribumi. Pasal dan ayat yang terkandung dalam Undang-undang ini akan diperdebatkan oleh siswa-siswa yang tergabung dalam kubu Humanis dan kubu Konservatif. 
TIO FATURHOMAN DAN TARUNASENA

ROLE PLAYING GAME TANPA GADGET (PENELITIAN TINDAKAN KELAS DALAM PEMBELAJARAN

SEJARAH DI KELAS XI IPS C MAN I KOTA BANDUNG)

d. Membuat instrumen penelitian. Terdapat 2 jenis instrumen yang digunakan, Instrumen Observasi dan Instrumen Tes Uraian. Instrumen Obervasi terdiri dari catatan lapangan, lembar penilaian performa siswa dan indikator penilaian performa siswa. Sedangkan instrumen tes uraian terdiri dari soal-soal uraian, kunci jawaban beserta pedoman penilaian, dan tabel penilaian tes uraian siswa.

Pada tindakan siklus pertama ini, penulis menerapkan metode Role Playing. Pelaksanaan Role Playing ini dilakukan dengan mengikuti skenario yang tercantum dalam Rencana Pelaksanaan Pembelajaran. Dalam pelaksanaan tindakan ini, Penulis dibantu oleh Partner Observer.

Pelaksanaan tindakan ini dilakukan dalam satu pertemuan pada tanggal tanggal 4 April 2018 pukul 14:30 sampai 16:00 WIB di kelas XI IPS C MAN I Kota Bandung. Pelaksanaan Tindakan di pertemuan ini dilakukan dalam langkahlangkah sebagai berikut :

a. Penulis membuka kegiatan pembelajaran dengan mengucapkan salam, mengecek kehadiran siswa dan mengkondisikan suasana kelas supaya tertib dan teratur.

b. Penulis memberikan pengenalan mengenai kegiatan Role Playing yang akan dilakukan hari ini. Penulis menjelaskan skenario yang akan dimainkan, peraturan permainan dan pembagian peran. Siswa dibagi menjadi 2 kelompok, kubu Konservatif yang menentang Politik Etis dan kubu Humanis yang mendukung Politik Etis.

c. Setelah semua siswa mendapat perannya masing-masing, Guru dengan dibantu para siswa mengatur ruang kelas hingga menyerupai ruang sidang parlemen. Kedua kelompok duduk saling berhadapan.

d. Penulis berperan sebagai moderator, membuka sidang dengan membahas keadaan ekonomi Belanda setelah perang Belgia dan Jawa, penerapan Kebijakan Culture Stelsel-nya van Den Bosch dan impact-nya pada ekonomi Belanda.

e. Penulis menuliskan rancangan pasal yang mengatur pemberian Irigasi gratis kepada pribumi. Siswa dari tiap kelompok memberikan tanggapan atas rancangan ini. Mereka berhak mengubah kata-kata yang tercantum dalam ayat ini, namun harus diperkuat dengan argumennya masing-masing.

f. Setelah merubah rancangan pasal Undang-undang irigasi, penulis mengadakan voting untuk menentukan persetujuan di kedua belah pihak mengenai Undang-undang tersebut.

g. Penulis menuliskan rancangan Undang-undang Pendidikan untuk Pribumi di papan tulis. Setiap siswa diberi kesempatan untuk menyatakan pendapat mengenai rancangan Undang-undang tersebut. Mereka berhak mengubah kata-kata yang terkandung dalam pasal tersebut.

h. Penulis mengadakan voting untuk mengetahui apakah Undang-undang pendidikan untuk pribumi layak untuk dikeluarkan.

i. Penulis menuliskan Rancangan Undang-undang Transmigrasi di papan tulis. Setiap siswa diberi kesempatan untuk menyatakan pendapat mengenai rancangan Undang-undang tersebut. Mereka berhak mengubah kata-kata yang terkandung dalam pasal tersebut. 
j. Penulis mengadakan voting untuk mengetahui apakah Undang-undang pendidikan untuk pribumi layak untuk dikeluarkan.

k. Penulis menyediakan selembar kertas dan meminta perwakilan dari tiap kubu untuk menandatangani kertas tersebut sebagai tanda Undang-undang Politik Etis disahkan.

1. Penulis menyuruh siswa untuk mengambil selembar kertas untuk mengerjakan 4 soal tes uraian seputar politik etis.

Hasil pelaksanaan tindakan ini dapat dilihat dari tabel nomor 1 yang memperlihatkan aktivitas siswa setelah melakukan kegiatan Role Playing.

Dari tabel 10.1 dapat diketahui bahwa pada Aktivitas Fisik, dari 32 siswa yang berpartisipasi dalam kegiatan Role Playing ini, hanya 11 siswa yang aktif memainkan terdapat 9 siswa yang masuk dalam kategori Di Atas Rata-rata. Siswa yang masuk dalam kategori ini terbukti memiliki kemampuan analisis, pemahaman, dan evaluasi yang tinggi.

Kategori selanjutnya adalah rata-rata yang baik pada aktivitas fisik maupun aktivitas mental memiliki frekuensi yang sama: 20 siswa. Siswa yang masuk dalam kategori ini kurang menunjukkan aktivititas fisiknya selama Role Playing berlangsung. Meskipun begitu, mereka fokus memperhatikan Proses Kegiatan Role Playing dari awal sampai akhir. Sedangkan pada aktivitas mental, mereka menulis jawaban itu dalam bentuk uraian yang kurang tepat.

Kategori Terakhir adalah Di Bawah Rata-rata. Pada Aktivitas fisik, terdapat 1 siswa yang masuk dalam kategori ini. Dia adalah siswa yang tidak mengikuti

Tabel 10. 1. Aktivitas Belajar Siswa Kelas XI IPS C Siklus I

\begin{tabular}{|c|c|c|c|c|}
\hline & \multicolumn{2}{|c|}{ Aktivitas Fisik } & \multicolumn{2}{|c|}{ Aktivitas Mental } \\
\hline Kategori & Frekuensi & \begin{tabular}{|l} 
Rentang \\
Nilai
\end{tabular} & Frekuensi & $\begin{array}{l}\text { Rentang } \\
\text { Nilai }\end{array}$ \\
\hline Di Atas Rata-rata & $\underline{11}$ & $\underline{82-100}$ & 9 & $75-85$ \\
\hline Rata-rata & $\underline{\underline{20}}$ & $40-45$ & $\underline{20}$ & $\underline{40-70}$ \\
\hline \begin{tabular}{|l} 
Di Bawah Rata- \\
rata
\end{tabular} & $\underline{1}$ & 25 & 3 & $\underline{0-35}$ \\
\hline
\end{tabular}

Sumber : Data Primer yang sudah diolah

perannya masing-masing dalam Role Playing. Siswa yang aktif ini masuk dalam kategori Di Atas Rata-rata karena perolehan nilai mereka yang terlampau sangat besar. Selama Role Playing berlangsung, mereka memanfaatkan kesempatan untuk menyatakan pendapat, menyanggah argumen dari pihak lawan dan memperkuat pernyataan rekan-rekan mereka. Sedangkan pada Aktivitas Mental, kegiatan Role Playing dari awal sampai akhir. Sedangkan pada aktivitas mental, terdapat 3 siswa yang masuk kategori Di Bawah Rata-rata. Dalam pengerjaan tes uraian, mereka memberikan jawaban singkat yang tidak tepat sasaran.

Dari pembahasan hasil pelaksanaan siklus I tersebut, penulis menemukan adanya kendalan yang masuk dalam Refleksi Siklus I sebagai berikut : 
TIO FATURHOMAN DAN TARUNASENA

ROLE PLAYING GAME TANPA GADGET (PENELITIAN TINDAKAN KELAS DALAM PEMBELAJARAN

SEJARAH DI KELAS XI IPS C MAN I KOTA BANDUNG)

a. Terjadi perilaku curang dari beberapa siswa berupa kegiatan menyontek.

b. Kurangnya waktu untuk memberikan materi dan arahan untuk kegiatan Role Playing.

c. Penulis sebagai Observer masih mendominasi kegiatan Role Playing.

d. Siswa dan guru menggunakan properti seadanya, properti yang digunakan sangat kurang baik dari segi kuantitas maupun kualitas.

Penulis melihat kesalahan dan kekurangan ini sebagai pelajaran bagi penulis untuk melaksanakan siklus selanjutnya supaya lebih baik. Berikut adalah usaha untuk memperbaiki kekurangan tersebut sekaligus meningkatkan kinerja siswa di siklus selanjutnya:

a. Memperketat pengawasan saat tes uraian berlangsung untuk mencegah terjadi perilaku curang seperti menyontek.

b. Alokasi waktu ditingkatkan menjadi 2 pertemuan atau $4 \times 45$ menit.

c. Di setiap penutupan kegiatan pembelajaran Memberikan apresiasi dan motivasi pada semua siswa untuk meningkatkan keaktifannya.

d. Observer berperan di balik panggung sebagai pengarah jalannya permainan

e. Observer membuat properti yang sesuai dengan skenario yang akan dimainkan

\section{Pelaksanaan Siklus II}

Pada pelaksanaan Siklus II ini, penulis masih melakukannya dalam 4 tahapan layaknya siklus sebelumnya. Meskipun begitu, terdapat banyak perubahan. Misalnya pada tahapan perencanaan di mana penulis merancang RPP, terdapat perubahan sebagai berikut :

a. Materi yang dibahas adalah pergerakan bangsa Indonesia di awal abad 20, mulai dari pendirian organisasi pergerakan nasional (Budi Utumo, Syarekat Islam dan Indische Partij) sampai peristiwa penting seperti Pemberontakan PKI dan Indonesia Menggugat.

b. Penulis membuat RPP ini untuk 2 pertemuan. Maka dari itu, dibuatkan 2 tabel langkah-langkah pembelajaran. Tabel pertama untuk pertemuan pertama di mana penulis dan siswa melakukan persiapan untuk pelaksanaan Role Playing pertemuan selanjutnya. Sedangkan Tabel kedua untuk pertemuan kedua di mana siswa melakukan Role Playing.

c. Skenario Role Playing yang tercantum dalam RPP ini adalah peragaaan ulang peristiwa Indonesia Menggugat, Pengadilan Sukarno atas tuduhan melakukan penggulingan terhadap Pemerintahan Kolonial Hindia Belanda.

d. Soal-soal Tes Uraian dikurangi dari 4 soal menjadi 3 soal. Setiap soal masingmasing menguji satu kemampuan mental siswa seperti Pemahaman, Analisis dan Evaluasi.

Selain menyusun RPP, Penulis juga membuat Properti yang mendukung jalannya kegiatan Role Playing. Propertiproperti dibuat khusus untuk pemeran utama seperti Sukarno, Jaksa, Pengacara, Hakim, Wakil Hakim dan Sekretaris Hakim. Setiap pemeran utama memiliki 
properti yang berbeda satu sama lain. Misalnya, Jaksa diberi properti berupa instruksi cara memerankan peran Jaksa dan barang bukti yang mendukung tuntutannya. Sedangkan pengacara mendapat properti berupa instruksi cara memerankan peran sebagai Pengacara dan Barang Bukti yang menyangkal tuntutan dari Jaksa. Selain membuat properti, penulis tetap mempersiapkan instrumen penelitian seperti lembar observasi, catatan lapangan dan lembar penilaian tes uraian.

Pertemuan pertama pada siklus II ini dilaksanakan pada tanggal 6 April 2018 pukul 10:00 WIB. Pada pertemuan ini, Penulis meluangkan waktu selama 90 menit ini untuk mempersiapkan siswa dalam pelaksanaan Role Playing di pertemuan kedua. Berikut adalah langkahlangkah yang ditempuh dalam pertemuan pertama ini :

a. Penulis menjelaskan sejarah berdirinya organisasi pergerakan bangsa Indonesia seperti Budi Utomo, Syarekat Islam dan Indische Partij.

b. Penulis menjelaskan kegiatan Role Playing yang akan dilaksanakan pada pertemuan selanjutnya. Mulai dari skenario, aturan bermain dan penokohan.

c. Penulis membagi peran utama (Sukarno, Pengacara, Jaksa, Hakim, Wakil Hakim dan Sekretaris Hakim) pada siswa-siswa yang mengajukan diri untuk memainkan peran itu. Setelah mendapat peran, penulis memberikan properti kepada mereka untuk memperdalam peran mereka masing-masing.

d. Penulis membagi siswa-siswa yang tidak kebagian peran menjadi 2 kubu, pro sukarno dan anti sukarno. kedua kubu ini adalah para penonton sidang Sukarno yang bisa dijadikan sebagai saksi.

e. Penulis menyuruh para siswa dari tiap kubu untuk membuat profil mereka sebagai calon saksi di pengadilan nanti. Setelah dibuatkan, mereka mengumpulkannya pada penulis.

Pertemuan Kedua dilaksanakan pada tanggal 18 April 2018. Peremuan kali ini diagendakan untuk melaksanakan kegiatan Role Playing Indonesia Menggugat. Seperti biasa, pada pelaksanaan ini penulis ditemani oleh Partner Observer. Berikut adalah langkah-langkah yang ditempuh :

a. Penulis memulai kegiatan pembelajaran dengan mengucapkan salam, memeriksa kehadiran siswa dan memastikan keadaan kelas menjadi kondusif.

b. Penulis dengan dibantu siswasiswa mengatur ruang kelas hingga menyerupai ruang pengadilan. Pemeran utama duduk di tempatnya masing-masing. Kubu Pro Sukarno duduk di barisan bangku di belakang Pengacara dan Sukarno. Sedangkan kubu Anti Sukarno duduk di belakang Jaksa.

c. Pemeran Hakim membuka pengadilan dengan mempersilahkan Jaksa untuk membacakan Tuntutan. Jaksa memberikan pernyataan dengan diperkuat bukti-bukti yang ada untuk menyudutkan Sukarno

d. Pengacara memberikan pernyataan dengan diperkuat bukti-bukti yang ada untuk membela Sukarno. Dia menghadirkan Sukarno sebagai Saksi pertama pada pengadilan. 
TIO FATURHOMAN DAN TARUNASENA

ROLE PLAYING GAME TANPA GADGET (PENELITIAN TINDAKAN KELAS DALAM PEMBELAJARAN SEJARAH DI KELAS XI IPS C MAN I KOTA BANDUNG)

e. Pengacara dan Jaksa menghadirkan Saksi. Mereka berhak memberi pertanyaan pada saksi yang dihadirkan oleh dirinya sendiri atau oleh pihak lawan.

f. Di penghujung pengadilan, Hakim berdiskusi dengan Wakil Hakim dan Sekretaris. Berdasarkan hasil diskusi itu, Hakim menjatuhkan Vonis pada Sukarno.

g. Setelah dijatuhkan Vonis, Sukarno membacakan potongan pidato Indonesi Menggugat di Depan Kelas.

h. Penulis mengapresiasi penampilan siswa dalam memainkan Role Playing.

i. Penulis memberikan Tes Uraian pada semua siswa, mereka harus menjawab 3 soal dalam selembar kertas.

Setelah melaksanakan Role Playing Indonesia Menggugat, penulis menemukan adanya perkembangan aktivitas fisik dan mental siswa jika dibandingkan dengan aktivitas belajar di siklus sebelumnya. Berikut adalah hasil dari pelaksanaan Siklus II

Dari tabel 10.2, dapat dilihat pada kategori Di Atas Rata-rata terjadi pengurangan frekuensi namun terjadi pula peningkatan rentang nilai pada aktivitas fisik. Siswa yang masuk dalam kategori ini adalah para pemeran utama dan penonton yang dipanggil sebagai saksi. Dengan peran yang mereka dapatkan, mereka memiliki kesempatan untuk menunjukkan aktivitas fisiknya dengan maksimal. Sedangkan pada Aktivitas mental, tidak ada peningkatan pada frekuensi namun Rentang Nilai aktivitas ini semakin meningkat.

Pada kategori rata-rata, tejadi peningkatan pada frekuensi dan rentang nilai dalam aktivitas fisik. Siswa dalam kategori ini adalah para penonton sidang. Selama Pengadilan berlangsung, mereka memperhatikannya dengan seksama. Selain itu, mereka juga responsif terhadap pernyataan baik dari pemeran utama dan penonton dari kubu lawan. Sedangkan pada aktivitas mental, terjadi pengurang pada frekuensi dan peningkatan pada rentang nilai.

Pada kategori Dibawah Rata-rata, terdapat 2 siswa yang tidak hadir dalam kegiatan Role Playing sehingga mendapat nilai terendah pada aktivitas fisik. Sedangkan pada aktivitas mental, terdapat 8 siswa yang masuk kategori Di Bawah Rata-rata. Empat di antaranya mendapat mendapat nilai o karena tidak mengikuti Tes Tertulis.

Berdasarkan pelaksanaan dan hasil kegiatan Role Playing di atas, Penulis masih menemukan adanya kendala dalam siklus ini sebagai berikut :

Tabel 10. 2. Aktivitas Belajar Siswa Kelas XI IPS C Siklus II

\begin{tabular}{|c|l|l|l|l|}
\hline & \multicolumn{2}{|c|}{ Aktivitas Fisik } & \multicolumn{2}{c|}{ Aktivitas Mental } \\
\hline Kategori & \multicolumn{1}{|c|}{ Frekuensi } & $\begin{array}{c}\text { R e n t a n g } \\
\text { Nilai }\end{array}$ & Frekuensi & $\begin{array}{c}\text { R e n t a n g } \\
\text { Nilai }\end{array}$ \\
\hline$\underline{\text { Di Atas Rata-rata }}$ & 9 & $90-100$ & 9 & $\underline{80-95}$ \\
\hline$\underline{\text { Rata-rata }}$ & $\underline{\mathbf{2 1}}$ & $71-75$ & $\underline{15}$ & $\underline{60-75}$ \\
\hline $\begin{array}{l}\text { Di Bawah Rata- } \\
\text { rata }\end{array}$ & $\underline{2}$ & $\underline{25}$ & $\underline{8}$ & $\underline{0-50}$ \\
\hline
\end{tabular}

Sumber : Data Primer yang sudah diolah 
a. Jumlah partisipan dalam kegiatan Role Playing menurun karena adanya ketimpangan antara pemeran utama dan pemeran penonton. Bagi Pemeran utama, mereka memiliki kesempatan yang luas untuk beraktivitas. Namun hal ini tidak dirasakan oleh pemeran penonton.

b. Terdapat dua siswa yang sebenarnya hadir di kelas namun tidak mengumpulkan hasil Tes Uraiannya.

Dalam menanggulangi kendala seperti yang dijelaskan di atas, penulis melakukan upaya-upaya penanggulangan sebagai berikut :

a. Skenario harus dibuat sesederhana mungkin dan memberikan kesempatan bagi setiap siswa untuk aktif.

b. Pembagian peran dilakukan secara berkelompok, setiap kelompok terdiri dari 5-6 siswa.

c. Dikarenakan penelitian ini bersifat partisipatif, penulis kembali terlibat sebagai pemain dalam Role Playing selanjutnya.

d. Memperketat pengawasan tes tertulis untuk menghindari perilaku curang dan memastikan semua siswa mengerjakan setiap soal tanpa terkecuali.

\section{Pelaksanaan Siklus III}

Sebelum melakukan tindakan, penulis terlebih dahulu melakukan perencanaan. Skenario yang akan dimainkan adalah peragaan Kongres Pemuda II. Skenario ini tercantum dalam RPP. Berdasarkan refleksi siklus II, penulis membuat perubahan sebagai berikut :

a. Materi yang disajikan adalah Sumpah Pemuda. Mulai dari Kongres Pemuda I, Kongres Pemuda II sampai pengaruh
Sumpah Pemuda pada kehidupan sekarang.

b. Pada penilaian aktivitas fisik, penulis berfokus pada oral activity, terutama pada penggunaan logat daerah selama siswa berbicara.

c. Pada tes tertulis, pertanyaan analisis yang awalnya menguji siswa dalam menemukan keterkaitan antara peristiwa masa lalu dengan masa kini diubah menjadi pertanyaan yang menguji keampuan siswa dalam menerapkan nilai-nilai peristiwa masa lalu dengan kehidupan masa kini.

Siklus III ini dilakukan dalam 2 pertemuan. Pertemuan pertama diagendakan untuk mempersiapkan siswa pada kegiatan Role Playing yang akan dilaksanakan pada pertemuan selanjutnya. Berikut adalah langkah-langkah dari pertemuan pertama pada tanggal 20 April 2018 di Kelas XI IPS C MAN I Kota Bandung :

a. Penulis menjelaskan Kongres Pemuda I pada siswa-siswa kelas XI IPS C melalui ceramah.

b. Penulis menjelaskan kegiatan Role Playing yang akan dilaksanakan pada pertemuan selanjutnya. Skenario yang akan dimainkan adalah peragaan Kongres Pemuda II.

c. Penulis membagi siswa menjadi 7 kelompok. Setiap siswa berembuk dengan kelompoknya masing-masing untuk menentukan suku atau daerah mana yang diwakili oleh mereka. Mereka harus menuliskan profil kelompoknya dalam selembar kertas.

d. Setelah mengetahui profil setiap kelompok, penulis mengajarkan pada tiap kelompok bagaimana caranya berbicara dan berperilaku seperti suku yang mereka perankan. 
TIO FATURHOMAN DAN TARUNASENA

ROLE PLAYING GAME TANPA GADGET (PENELITIAN TINDAKAN KELAS DALAM PEMBELAJARAN SEJARAH DI KELAS XI IPS C MAN I KOTA BANDUNG)

Pertemuan kedua dilakukan pada tanggal 2 Mei 2018 pukul 14:30 di Kelas XI IPS C. Pertemuan ini diagendakan untuk melaksanakan kegiatan Role Playing yang telah dipersiapkan pada pertemuan sebelumnya. Seperti siklus sebelumnya, penulis ibantu oleh partner observer dalam kegiatan Role Playing ini. berikut adalah langkah-langkah yang ditempuh dalam Role Playing ini :

a. Penulis membuka kegiatan pembelajaran dengan mengucapkan salam, memeriksa kehadiran siswa dan mengkondusifkan kelas.

b. Penulis dan siswa mengatur ruang kelas sehingga menyerupai ruang kongres. Setelah itu, semua siswa duduk bersama kelompoknya di tempat mereka masing-masing.

c. Penulis berperan sebagai moderator kongres, membuka acara dengan mengucapkan salam dan memperkenalkan diri.

d. Setiap kelompok memperkenalkan diri dengan diwakili oleh satu orang anggota. Masing-masing anggota harus berbicara dengan logat suku yang mereka perankan.

e. Penulis menceritakan keadaan dan masalah yang terjadi di desanya akibat Kolonialisme Belanda. Kemudian semua kelompok menceritakan masalah di masing-masing daerahnya. f. Penulis menceritakan pengalamannya dalam melawan kolonialisme secara fisik. Setelah itu, semua kelompok menceritakan pengalaman mereka mengenai perlawanan fisik di daerah masing-masing.

g. Penulis mengangkat isu upaya persatuan, yaitu isu Bahasa pemersatu. Setiap kelompok berhak mengajukan bahasa apa yang patut menjadi bahasa persatuan.

h. Penulis mengadakan voting untuk menentukan bahasa persatuan.

i. Setelah mengadakan voting, penulis mengajak semua siswa untuk menyanyikan lagu Indonesia Raya.

j. Penulis mengapresiasi penampilan siswa selama melakukan Role Playing.

k. Penulis mengadakan Tes Uraian di mana semua siswa harus menjawab tiga pertanyaan dalam selembar kertas.

Berdasarkan pelaksanaan Role Playing di atas, penulis menemukan adanya peningkatan aktivitas baik dari segi fisik maupun mental. berikut adalah Tabel yang menyajikan perkembangan aktivitas belajar siswa setelah melakukan Role Playing :

Dari tabel 10.3, dapat dilihat adanya peningkatan baik dari segi kuantitas (frekuensi) maupun dari segi kualitas

Tabel 10. 3. Aktivitas Belajar Siswa Kelas XI IPS C Siklus III

\begin{tabular}{|c|c|c|c|c|}
\hline & \multicolumn{2}{|c|}{ Aktivitas Fisik } & \multicolumn{2}{|c|}{ Aktivitas Mental } \\
\hline Kategori & Frekuensi & $\begin{array}{l}\text { Rentang } \\
\text { Nilai }\end{array}$ & Frekuensi & \begin{tabular}{|l} 
Rentang \\
Nilai
\end{tabular} \\
\hline Di Atas Rata-rata & $\underline{12}$ & 95-100 & $\underline{10}$ & 80-95 \\
\hline$\underline{\text { Rata-rata }}$ & $\underline{16}$ & 70 & 15 & $60-75$ \\
\hline $\begin{array}{l}\text { Di Bawah Rata- } \\
\text { rata }\end{array}$ & 4 & $\underline{25}$ & 7 & $0-55$ \\
\hline
\end{tabular}

Sumber : Data Primer yang sudah diolah 
(rentang nilai). Pada kategori di atas ratarata, terdapat 12 siswa yang memperoleh nilai dari 95 sampai 100 dalam aktivitas fisik. Mereka adalah siswa-siswa yang angkat bicara dan menunjukkan aktivitas mental yang maksimal selama Role Playing berlangsung. Sedangkan pada aktivitas mental, terdapat 10 siswa yang mampu memberikan uraian yang jelas dan memuaskan mengenai sumpah pemuda. Mulai dari pemahaman, analisis sampai evaluasi.

Sedangkan kategori Rata-rata, terdapat 16 siswa yang kurang maksimal dalam menunjukkan aktivitas fisiknya. Meskipun tidak angkat bicara selama Role Playing, mereka mampu memperhatikan jalanya kegiatan dengan seksama. Tak seorangpun yang melakukan kegiatan lain seperti tidur, main gadget dan lain-lain. selain itu, mereka juga responsif terhadap pernyataan-pernyataan dari siswa yang aktif. Respon yang diberikan pada umumnya berupa teriakan, ejakan, seruan protes, tawa dan sebagainya. Sedangkan pada aktivitas fisik, terdapat 16 siswa yang belum maksimal dalam menjelaskan, menganalisis dan menganalisa peristiwa yang diperagakan.

Sedangkan pada kategori Di Bawah Rata-rata, terdapat 4 siswa yang tidak mengikuti kegiatan Role Playing sehingga mereka mendapat nilai terendah. Sedangkan pada aktivitas mental, terdapat 7 siswa yang mendapat nilai terendah. Empat di antaranya adalah siswa yang tidak mengikuti kegiatan tes uraian, sedangkan sisanya menjawab tes uraian secara asal-asalan.

Dari penjelasan di atas telah dibeberkan proses dan hasil dari penerapan Role Playing yang berlangsung selama 1 bulan lebih dalam 3 siklus. Menurut Morgan dan Kawan-kawan (dalam Soekamto \& Winataputra, 1997), tujuan dari belajar adalah memperoleh perubahan fisik maupun mental melalui suatu proses latihan atau penanaman pengalaman. Pernyataan ini merupakan indikator dari keberhasilan Penelitian Tindakan Kelas. Penelitian ini akan dinyatakan berhasil jika ditemukan adanya perubahan dan peningkatan pada aktivitas belajar siswa.

Pada tahapan pelaksanaan dari tiap siklus, penulis menemukan adanya aktivitas siswa yang menjadi bukti kebenaran dari tiga teori belajar seperti teori kognitif, teori konstruktivistik dan teori sibernetik. Pada teori kognitif, penulis melihat siswa-siswa kelas XI IPS C belajar dengan berinteraksi dengan lingkungan sekitarnya saat melakukan kegiatan Role Playing. Sebagai bukti, penulis melihat pada siklus II, para pemeran utama dan saksi memanipulasi properti yang ada untuk menghidupkan peran mereka masing-masing. Hal ini sejalan dengan penjelasan Piaget mengenai belajar sebagai proses interaksi antara siswa dengan lingkungannya untuk memahami sesuatu (Mukhlihas, 2015; Surya, 2003).

Selain Piaget, penelitian ini juga membuktikan Free Discovery Learning dari Bruner yang termasuk dalam Teori Kognitif. Bruner (dalam Thobroni dan Mustafa 2008), menjelaskan supaya siswa mampu memahami suatu konsep atau teori, siswa harus melihat atau memperagakan bentuk kongkrit dari konsep atau teori itu. Hal ini dibuktikan pada pelaksanaan siklus I di mana siswasiswa memperagakan Perdebatan Kubu Humanis dan Konservatif dalam Sidang Parlemen Belanda untuk memahami konsep Politik Etis. 
TIO FATURHOMAN DAN TARUNASENA

ROLE PLAYING GAME TANPA GADGET (PENELITIAN TINDAKAN KELAS DALAM PEMBELAJARAN SEJARAH DI KELAS XI IPS C MAN I KOTA BANDUNG)

Pada penelitian ini pula, penulis menemukan pembuktian dari Konsep Belajar Bermakna dari David Ausubel. Menurut Ausubel belajar adalah proses di mana siswa mengkaitkan pengetahuan dari guru dengan kenyataan yang ada di sekitar siswa (Ausubel, 1963; Suparno, 1997). Proses pengkaitan pengetahuan dan kenyataan ini dapat dilihat pada Tes Uraian, tepatnya uraian yang dibuat para siswa untuk menjawaba pertanyaan yang menguji kemampuan analisis.

Teori belajar selanjutnya adalah Teori Konstruktivistik yang menjelaskan bahwa pengetahuan adalah sebuah bangunan yang disusun oleh informasi lama, pengalaman dan insight baru dari lingkungannya (Ummi dan Mulyaningsih, 2016). Konsep yang paling signifikan dalam PTK ini adalah Konstruktivisme Sosial dari Vygotski. Beliau menjelaskan bahwa pengetahuan dibentuk dari interaksi siswa dengan orang-orang di sekitarnya (Danoebroto, 2015). Dari setiap siklus penulis melihat siswa mengembangkan pengetahuannya masing-masing dengan berinteraksi dengan rekan-rekannya melalui dialog. Mereka mendiskusikan dan memperdebatkan suatu isu untuk memahaminya.
Teori terakhir adalah Teori Sibernetik yang menjelaskan cara berpikir manusia dianalogikan dengan cara kerja komputer dimana informasi dari luar adalahfeedback yang diproses, dikategorikan, dikonversi dan diarsipkan ke dalam otak. Informasi tersebut kemudian diolah menjadi produk baru berupa tindakan, pernyataan dan lain-lain (Abror, 1993). Penerapan teori ini dapat dilihat ketika siswa melakukan Role Playing dengan diarahkan oleh Penulis. Siswa diberi feedback berupa perintah dari penulis. Perintah tersebut diproses menjadi perilaku yang sesuai dengan perintah tersebut.

Menurut Hopkins dan Issac, penelitian tindakan kelas dilakukan dengan tujuan untuk memahami dan mengatasi masalah dalam kelas sekaligus meningkatkan kinerja siswa dalam belajar (Mardiani, 2015; Muslich, 2010). Berikut adalah peningkatan aktivitas fisik dan mental siswa dari tiga siklus :

Dari Tabel 10.4 dapat dilihat adanya perkembangan baik dari kuantitas (frekuensi) maupun kualitas (rentang nilai). Peningkatan pada segi kuantitas terjadi secara dinamik pada setiap kategori. Misalnya pada kategori Di Atas Rata-rata,

Tabel 10. 4. Peningkatan Aktivitas Fisik siswa dari bebrbagai siklus

\begin{tabular}{|c|c|c|c|c|c|c|}
\hline \multirow[b]{2}{*}{ Kategori } & \multicolumn{2}{|l|}{ Siklus 1} & \multicolumn{2}{|l|}{ Siklus 2} & \multicolumn{2}{|l|}{ Siklus 3} \\
\hline & Frekuensi & \begin{tabular}{|l} 
Rentang \\
Nilai
\end{tabular} & Frekuensi & \begin{tabular}{|l} 
Rentang \\
Nilai
\end{tabular} & Frekuensi & $\begin{array}{l}\text { Rentang } \\
\text { Nilai }\end{array}$ \\
\hline $\begin{array}{lll}\text { Di } & \text { Atas Rata- } \\
& \text { rata } & \\
\end{array}$ & $\underline{11}$ & $\underline{82-100}$ & 9 & 90-100 & $\underline{12}$ & $95-100$ \\
\hline Rata-rata & $\underline{20}$ & $40-45$ & 21 & $71-75$ & $\underline{16}$ & 70 \\
\hline $\begin{array}{c}\text { Di Bawah Rata- } \\
\text { rata }\end{array}$ & $\underline{1}$ & 25 & 2 & 25 & 4 & 25 \\
\hline
\end{tabular}

Sumber : Data Primer yang sudah diolah 
terjadi penurunan jumlah pastisipan dari siklus I ke Siklus II. Pada siklus 3, jumlah partisipan meningkat. Sedangkan pada segi kualitas, perkembangan terjadi secara signifikan pada kategori Di Atas Rata-rata. Sedangkan pada kategori Rata-rata dan Di Bawah Rata-rata, perkembangan terjadi secara dinamik.

Dari Tabel 10.5 dapat dilihat terjadinya perkembangan dalam aktivitas mental. Perkembangan tersebut berbeda jika dibandingkan dengan perkembangan aktivitas fisik. Sering ditemukan perkembangan yang stagnant baik pada segi kuantitas maupun kualitas. nilai aktivitas fisik siswa dari setiap siklus.

2. Penerapan Metode Role Playing dapat meningkatkan aktivitas mental siswa. buktinya dapat dilihat dari peningkatan rentang nilai tes uraian siswa dari setiap siklus.

Penulis menyarankan pada pihak sekolah untuk memanfaatkan karya tulis ini sebagai referensi dalam menyelesaikan permasalahan siswa dalam mempelajari sejarah. Selain itu, Penulis juga menyarankan para guru untuk melakukan penelitian tindakan kelas

Tabel 10. 5. Peningkatan Aktivitas Mental siswa dari bebrbagai siklus

\begin{tabular}{|c|c|c|c|c|c|c|}
\hline \multirow[b]{2}{*}{ Kategori } & \multicolumn{2}{|l|}{ Siklus 1} & \multicolumn{2}{|l|}{ Siklus 2} & \multicolumn{2}{|l|}{ Siklus 3} \\
\hline & Frekuensi & $\begin{array}{l}\text { Rentang } \\
\text { Nilai }\end{array}$ & Frekuensi & $\begin{array}{l}\text { Rentang } \\
\text { Nilai }\end{array}$ & Frekuensi & $\begin{array}{l}\text { Rentang } \\
\text { Nilai }\end{array}$ \\
\hline $\begin{array}{lll}\text { Di Atas Rata- } & \text { rata }\end{array}$ & 9 & $75-85$ & 9 & $80-95$ & $\underline{10}$ & $\underline{80-95}$ \\
\hline Rata-rata & $\underline{20}$ & $40-70$ & 15 & $60-75$ & 15 & $\underline{60-75}$ \\
\hline$\frac{\text { Di Bawah Rata- }}{\underline{\text { rata }}}$ & 3 & $\underline{0-35}$ & 8 & $0-50$ & 7 & $\underline{0-55}$ \\
\hline
\end{tabular}

Sumber : Data Primer yang sudah diolah

\section{SIMPULAN}

Berdasarkan pembahasan mengenai pelaksanaan dan hasil penelitian tindakan kelas pada Sub bab sebelumnya. Dapat disimpulkan bahwa Penerapan Metode Role Playing sangat berpengaruh pada perkembangan aktivitas belajar siswa Kelas XI IPS C MAN I Kota Bandung. berikut adalah rincian dari kesimpulan tersebut :

1. Penerapan Metode Role Playing dapat meningkatkan Aktivitas Fisik siswa elas XI IPS C MAN I Kota Bandung. Buktinya dapat dilihat pada peningkatan jumlah partisipan dan ketika menemukan adanya permasalahan aktivitas siswa. Terakhir, penulis menyarankan pada penelitian selanjutnya untuk menggunakan karya tulis ini sebagai referensi

\section{DAFTAR PUSTAKA}

\section{Buku}

Abror, A. (1993). Psikologi Pendidikan. Yogyakarta: Tiara Wacana.

Afif, M. (2012). Peningkatan Aktivitas dan Prestasi Belajar Siswa Pada Mata Pelajaran IPS Materi Perjuangan Melawan Penjajah Melalui 
TIO FATURHOMAN DAN TARUNASENA

ROLE PLAYING GAME TANPA GADGET (PENELITIAN TINDAKAN KELAS DALAM PEMBELAJARAN SEJARAH DI KELAS XI IPS C MAN I KOTA BANDUNG)

Pembelajaran Koperatif Tipe Jigsaw II Di Kelas $V$ SD $N 3$ Linggasari. (Skripsi). Fakultas Keguruan dan Ilmu Pendidikan, Universitas Muhammadiyah Purwokerto.

Arifin, Z. (2011). Penelitian Pendidikan Metode dan Paradigma Baru. Bandung: PT. Remaja Rosdakarya.

Ausubel, D. P. (1963). The Psychology of Meaningful Verbal Learning. New York: Grune and Stratton.

Djamarah, S. B. (2002). Psikologi Belajar. Jakarta: Rineka Cipta.

Mardiani, T. (2015). Penerapan Metode Mind Map dalam Pembelajaran IPA di SD. (Skripsi), Fakultas Ilmu Pendidikan, Universitas Pendidikan Indonesia, Bandung.

Muslich, M. (2010). Melaksanakan PTK Penelitian Tindakan Kelas Itu Mudah. Jakarta: PT Bumi Aksara.

Soekamto, T dan Winataputra, U. S. (1997). Teori Belajar dan Modelmodel. Pembelajaran. Jakarta: Dirjen Dikti, Depdikbud.

Sugiarto, T. (1997). Metode Penelitian Pendidikan. Bandung: Alfabeta.

Suparno, P. (2006). Perkembangan Kognitif Jeiu an Piaget. Yogyakarta: Kanisius.

Surya, M. (2003). Psikologi Pembelajaran dan Pengajaran. Bandung: Yayasan Bhakti Winaya.

Susanto, A. (2013). Teori Belajar dan Pembelajaran di Sekolah Dasar. Jakarta: Kencana Prenada Media Group.

Thobroni, M dan Mustofa, A. (2011). Belajar \& Pembelajaran. Yogjakarta: Ar-Russ Media.
Trianto. (2010). Model Pembelajaran Terpadu Konsep, Strategi dan Implementasinya. Jakarta: Bumi Aksara.

Wiriaatmadja,R.(2007).MetodePenelitian Tindakan Kelas untuk Meningkatkan Kinerja Guru dan Dosen. Bandung: PT Remaja Rosdakarya.

Zaini, dkk. (2008). Strategi Pembelajaran Aktif. Yogyakarta: Pustaka Insan Madani.

\section{Jurnal}

Danoebroto, S.W. (2015). Teori Belajar Konstruktivistik Piaget dan Vygotsky. Indonesian Digital Journal of Mathematics and Education, 2, 191198.

Maharani, dkk. (2018). Penggunaan Strategi Pembelajaran Peer Lesson untuk Meningkatkan Kecerdasan Interpersonal Siswa dalam Pembelajaran Sejarah (Penelitian Tindakan Kelas di Kelas X MIA 7 SMA Negeri 2 Cimahi). FACTUM: Jurnal Sejarah dan Pendidikan Sejarah, 7, (1), 44-52.

Mukhlisah. (2015). Pengembangan Kognitif Jean Piaget dan Peningkatan Belajar Anak Diskalkulia (Studi Kasus Pada MI Pangeran Dipenogoro Surabaya). Jurnal Kependidikan Islam, 6, 118-143.

Ummi, H. U dan Mulyaningsih, I. (2016). Penerapan Teori Konstruktivistik pada Pembelajaran Bahasa Arab di IAIN Syekh Nurjati Cirebon. Journal Indonesian Language Education and Literature, 1, 42-52. 
FACTUM

Volume 8 No.1, April 2019

\section{Internet}

Aedi, N. (2010). Pengolahan dan Analisis

Data Hasil Penelitian. diakses

dari http://file.upi.edu/Direktori/

DUAL-MODES / PENELITIAN_

PENDIDIKAN/BBM_8.pdf. 